\title{
Future consequences of decreasing marginal production efficiency in the high-yielding dairy cow
}

\author{
U. Moallem ${ }^{1}$ \\ Department of Ruminant Science, Institute of Animal Sciences, the Volcani Center, PO Box 6, Bet-Dagan, 50250 Israel
}

\begin{abstract}
The objectives were to examine the gross and marginal production efficiencies in high-yielding dairy cows and the future consequences on dairy industry profitability. Data from 2 experiments were used in acrosstreatments analysis $(\mathrm{n}=82$ mid-lactation multiparous Israeli-Holstein dairy cows). Milk yields, body weights $(\mathrm{BW})$, and dry matter intakes (DMI) were recorded daily. In both experiments, cows were fed a diet containing 16.5 to $16.6 \%$ crude protein and net energy for lactation $\left(\mathrm{NE}_{\mathrm{L}}\right)$ at $1.61 \mathrm{Mcal} / \mathrm{kg}$ of dry matter $(\mathrm{DM})$. The means of milk yield, BW, DMI, $\mathrm{NE}_{\mathrm{L}}$ intake, and energy required for maintenance were calculated individually over the whole study, and used to calculate gross and marginal efficiencies. Data were analyzed in 2 ways: (1) simple correlation between variables; and (2) cows were divided into 3 subgroups, designated low, moderate, and high DMI (LDMI, MDMI, and HDMI), according to actual DMI per day: $\leq 26 \mathrm{~kg}(\mathrm{n}=27) ;>26$ through $28.2 \mathrm{~kg}(\mathrm{n}=28)$; and $>28.2 \mathrm{~kg}(\mathrm{n}=27)$. The phenotypic Pearson correlations among variables were analyzed, and the GLM procedure was used to test differences between subgroups. The relationships between milk and fat-corrected milk yields and the corresponding gross efficiencies were positive, whereas BW and gross production efficiency were negatively correlated. The marginal production efficiency from DM and energy consumed decreased with increasing DMI. The difference between BW gain as predicted by the National Research Council model (2001) and the present measurements increased with increasing DMI $(\mathrm{r}=0.68)$. The average calculated energy balances were 1.38, 2.28, and $4.20 \mathrm{Mcal} / \mathrm{d}$ (standard error of the mean $=0.64$ ) in the LDMI, MDMI, and HDMI groups, respectively. The marginal efficiency for milk yields from DMI or energy consumed was highest in LDMI, intermediate in MDMI, and lowest in HDMI. The predicted BW gains for the whole study period were $22.9,37.9$, and $75.8 \mathrm{~kg}$
\end{abstract}

Received October 7, 2015.

Accepted December 21, 2015.

${ }^{1}$ Corresponding author: uzim@volcani.agri.gov.il for the LDMI, MDMI, and HDMI groups, respectively. The present study demonstrated that marginal production efficiency decreased with increasing feed intake. Because of the close association between production and intake, the principle of diminishing marginal productivity may explain why increasing milk production (and consequently increasing intake) does not always enhance profitability. To maintain high production efficiency in the future, more attention should be given to optimizing rather than maximizing feed intake, a goal that could be achieved by nutritional manipulations that would increase digestibility or by using a diet of denser nutrients that would provide all nutritional requirements from lower intake.

Key words: dairy cow, production efficiency, gross efficiency, marginal efficiency

\section{INTRODUCTION}

Feed costs constitute 50 to $60 \%$ of the overall costs in dairy production; therefore, increasing feed efficiency has a major effect on dairy industry profitability. Feed efficiency in the dairy industry also has consequences for environmental issues such as greenhouse gas production, carbon footprint, methane emission, nitrogen excretion, and so on (Connor et al., 2012; Reed et al., 2015). Capper et al. (2009) estimated that, because of improvements in the modern dairy cow, the carbon footprint associated with production of $1 \mathrm{~kg}$ of milk was 63\% less in 2007 than in 1944.

Intensive selection and improvements in nutritional and management techniques have markedly increased milk yields of dairy breeds worldwide and this, in turn, has increased their gross production efficiency. Simultaneously, however, feed intake was increased; Veerkamp (1998) reviewed several studies and found that the genetic correlation between yield and intake ranged from 0.46 to 0.65 . The rate of passage of digesta increases as feed intake increases, and decreasing the retention time of digesta in the rumen decreases feed digestibility (Colucci et al., 1982) and, consequently, the energy derived from feed. Gabel et al. (2003) found reductions of 4.1\% in energy digestibility and $1.6 \%$ in diet $\mathrm{NE}_{\mathrm{L}}$ content 
for each increase in multiple of maintenance unit (total $\mathrm{ME} / \mathrm{ME}$ for maintenance).

Efficiency of conversion of feed into yields (mainly of milk and body mass) comprises maintenance cost and production cost. Although we deal with a biological system, these terms could be treated as economic concepts, with maintenance cost considered as fixed cost and production cost a marginal cost. According to a basic principle in production economics, although increasing one input (production cost) while keeping other inputs (maintenance cost) constant may initially increase output, further increases in the variable input will have increasingly limited effects, and eventually no effect or a negative effect on output. In light of the decreasing digestibility associated with increasing yields and intake, the premise in the present study is that the principle of diminishing production efficiency also applies to the high-yielding cow that consumes a large amount of feed. Therefore, the present objectives were to examine the gross and marginal efficiencies for producing milk traits in high-yielding dairy cows, and to assess future consequences for dairy industry profitability and development.

\section{MATERIALS AND METHODS}

Data from 2 experiments were used in an acrosstreatment analysis to examine the gross and marginal efficiencies of production. Both experiments were conducted at the Volcani Center's experimental dairy farm, in Bet-Dagan, Israel, according to protocols approved by the Volcani Center Animal Care Committee. The first study lasted $98 \mathrm{~d}$ and the second study $91 \mathrm{~d}$. The average parity number was $2.9 \pm 1.1$ and $2.9 \pm 0.9$ in the first and second study, respectively. The average DIM during the study period were $157.3 \pm 72$ and 183 \pm 45 in the first and second study, respectively.

In each study, 42 multiparous high-yielding IsraeliHolstein dairy cows were housed in a covered loosehousing pen with adjacent outside yards equipped with a real-time electronic individual feeding system. Each feeding station included an individual identification system (I.D. tag; S.A.E. Kibbutz Afikim, Israel) that allowed each cow to enter a specific feeding station and automatically recorded each meal.

In both studies, cows were fed a typical Israeli dairy cow ration that contained, per kilogram of DM, 16.5 to $16.6 \% \mathrm{CP}$ and $1.61 \mathrm{Mcal}$ of $\mathrm{NE}_{\mathrm{L}}$ (Table 1). The $\mathrm{NE}_{\mathrm{L}}$ values for feedstuffs in rations were determined according to NRC (2001) model, for cows at $4 \times$ maintenance.

Cows were fed once daily at $1000 \mathrm{~h}$ with $105 \%$ of the expected intake, which was adjusted daily according to the preceding day's intake. Cows were milked 3 times daily; milk yields were recorded electronically, and the cows were weighed automatically after each milking with a walking electronic scale (S.A.E. Afikim). Milk samples were collected from 3 consecutive milkings: every week in experiment 1 , and every 2 wk in experiment 2. Samples were analyzed for milk fat, protein, lactose, and urea by infrared analysis (standard IDF 141C:2000; IDF, 2000) at the laboratories of the Israeli Cattle Breeders' Association (Caesarea, Israel). Somatic cell counts were determined in the same laboratory.

\section{Calculations}

Energy Calculations. Energy content in milk and energy balance (EB) were calculated by using the NRC (2001) equations, as follows:

$$
\begin{gathered}
\mathrm{NE}_{\mathrm{c}}=\left(\mathrm{NE}_{\mathrm{L}} \text { per } \mathrm{kg} \text { of } \mathrm{DM}\right) \times \mathrm{DMI} \\
\mathrm{NE}_{\mathrm{M}}=\mathrm{BW}^{0.75} \times 0.08 \times 1.1
\end{gathered}
$$

Table 1. Ingredients and chemical composition (\% of DM) of the

\begin{tabular}{|c|c|c|}
\hline \multirow[b]{2}{*}{ Item } & \multicolumn{2}{|c|}{ Treatment } \\
\hline & Experiment 1 & Experiment 2 \\
\hline \multicolumn{3}{|l|}{ Ingredient } \\
\hline Corn grain, ground & 20.7 & 14.7 \\
\hline Barley grain, rolled & 6.5 & 5.6 \\
\hline Wheat grain, rolled & 4.4 & 2.7 \\
\hline Soybean meal & 2.2 & 1.7 \\
\hline Rapeseed meal & 6.8 & 6.9 \\
\hline Sunflower meal & - & 5.7 \\
\hline Cottonseed & 2.1 & 2.4 \\
\hline Wheat bran & 0.9 & 9.2 \\
\hline Wheat silage & 19.1 & 6.1 \\
\hline Corn silage & — & 21.2 \\
\hline Oats hay & 11.2 & 7.6 \\
\hline Clover hay & - & 1.9 \\
\hline Gluten feed & 13.4 & 0.7 \\
\hline Distillers dried grains & 5.8 & 7.6 \\
\hline By-product of dairy industry & 2.6 & - \\
\hline Calcium soap of fatty acids & 1.9 & 3.4 \\
\hline Urea & 0.1 & 0.3 \\
\hline Limestone & 0.3 & 0.3 \\
\hline Calcium bicarbonate & 1.0 & 0.8 \\
\hline Salt & 1.0 & 1.2 \\
\hline Vitamins and minerals $^{1}$ & 0.1 & 0.1 \\
\hline \multicolumn{3}{|l|}{ Chemical composition } \\
\hline $\mathrm{NE}_{\mathrm{L}},{ }^{2} \mathrm{Mcal} / \mathrm{kg}$ of $\mathrm{DM}$ & 1.61 & 1.61 \\
\hline $\mathrm{CP}$ & 16.5 & 16.6 \\
\hline $\mathrm{NDF}$ & 30.6 & 33.1 \\
\hline Forage NDF & 17.0 & 18.3 \\
\hline Ether extract & 5.1 & 6.6 \\
\hline $\mathrm{Ca}$ & 0.9 & 0.8 \\
\hline $\mathrm{P}$ & 0.5 & 0.5 \\
\hline
\end{tabular}
experimental diets

${ }^{1}$ Contained (per kg): 20,000,000 IU of vitamin A, 2,000,000 IU of vitamin D, 15,000 IU of vitamin E, 6,000 $\mathrm{mg}$ of Mn, 6,000 $\mathrm{mg}$ of $\mathrm{Zn}, 2,000$ $\mathrm{mg}$ of $\mathrm{Fe}, 1,500 \mathrm{mg}$ of $\mathrm{Cu}, 120 \mathrm{mg}$ of I, $50 \mathrm{mg}$ of Se, and $20 \mathrm{mg}$ of Co. ${ }^{2}$ Calculated using the NRC (1989) values with a few Israeli adjustments. 
Energy-corrected milk (i.e., energy output in milk):

$$
\begin{gathered}
\mathrm{ECM}=\text { milk }(\mathrm{kg}) \times\{[0.0929 \times(\text { fat \% })] \\
+[0.0547 \times(\text { protein \% })]+[0.0395 \times(\text { lactose \% })]\} ; \\
\mathrm{EB}=\mathrm{NE}_{\mathrm{c}}-\left(\mathrm{NE}_{\mathrm{M}}+\mathrm{ECM}\right) ;
\end{gathered}
$$

where $\mathrm{NE}_{\mathrm{c}}=$ net energy consumed.

Gross and Marginal Efficiency Calculations. The means of milk FCM (4\%) and ECM yields, BW, DMI, $\mathrm{NE}_{\mathrm{L}}$ intake, and energy required for maintenance were calculated individually for each cow for the whole period of each study.

The gross (conversion) efficiencies were calculated as follows:

$$
\begin{aligned}
& \text { gross efficiency for milk production = } \\
& \text { milk yield }(\mathrm{kg}) / \mathrm{DMI}(\mathrm{kg}), \\
& \text { gross efficiency for FCM production = } \\
& 4 \% \text { FCM yield }(\mathrm{kg}) / \mathrm{DMI}(\mathrm{kg}), \\
& \text { gross efficiency for ECM production = } \\
& \text { ECM }(\text { Mcal }) / \mathrm{DMI}(\mathrm{kg}) .
\end{aligned}
$$

The marginal efficiencies were calculated as follows: With respect to DMI,

marginal efficiency for milk $=$ milk yield/[DMI - $\left(\mathrm{NE}_{\mathrm{M}} /\right.$ energy density in diet $\left.)\right]$,

$$
\text { marginal efficiency for FCM }=\text { FCM }(4 \%)
$$$$
\text { yield/[DMI - } \left.\left(\mathrm{NE}_{\mathrm{M}} / \text { energy density in diet }\right)\right] \text {, }
$$$$
\text { marginal efficiency for ECM = ECM (Mcal)/ }
$$

$$
\text { [DMI - ( } \left.\left.\mathrm{NE}_{\mathrm{M}} / \text { energy density in diet }\right)\right] \text {. }
$$

With respect to energy,

$$
\text { marginal efficiency for milk }=
$$$$
\text { milk yield }(\mathrm{kg}) /\left(\mathrm{NE}_{\mathrm{c}}-\mathrm{NE}_{\mathrm{M}}, \mathrm{Mcal}\right) \text {, }
$$$$
\text { marginal efficiency for } 4 \% \mathrm{FCM}=
$$$$
\left.4 \% \mathrm{FCM} \text { yield/( } \mathrm{NE}_{\mathrm{c}}-\mathrm{NE}_{\mathrm{M}}, \mathrm{Mcal}\right) \text {, }
$$$$
\text { marginal efficiency for ECM = }
$$$$
\operatorname{ECM}\left(\text { Mcal) } /\left(\mathrm{NE}_{\mathrm{c}}-\mathrm{NE}_{\mathrm{M}}, \mathrm{Mcal}\right)\right. \text {. }
$$

The EB was calculated individually and the predicted BW gain was calculated according to the NRC (2001) model: for $1 \mathrm{~kg}$ of $\mathrm{BW}$ gain, $\mathrm{EB}=+4.9 \mathrm{Mcal}$; and for 1 $\mathrm{kg}$ of BW loss, $\mathrm{EB}=-4.3 \mathrm{Mcal}$. The difference between measured and predicted BW gain was calculated individually from the mean values of each cow.

Further analysis was applied to the same data. Cows were sorted according to the average DMI and divided into 3 subgroups (equal number of cows in each subgroup), designated as low DMI (LDMI), medium DMI (MDMI), and high DMI (HDMI): $\leq 26 \mathrm{~kg}$ of $\mathrm{DM} / \mathrm{d}(\mathrm{LDMI} ; \mathrm{n}=27) ;>26$ through $28.2 \mathrm{~kg}$ of $\mathrm{DM} / \mathrm{d}$ (MDMI; $\mathrm{n}=28$ ); and $>28.2 \mathrm{~kg}$ of DM/d (HDMI; $\mathrm{n}$ $=27$ ). All yield, intake, and efficiency analyses were applied according to these 3 groups.

\section{Statistical Analysis}

As described above, the mean values of milk and $4 \%$ FCM yields, energy output in milk, BW, DMI, energy intake, and energy required for maintenance were calculated individually for each cow for the whole period of each study. One cow was excluded from the analysis because of severe mastitis and another because of recurring bloat during the study period. Yield and efficiency data, and all other variables were analyzed within the same 3 subgroups by using the General Linear Model (GLM) procedure, version 9.2 of SAS Institute (2002). The model used was

$$
\mathrm{Y}_{\mathrm{ijk}}=\mu+\mathrm{G}_{\mathrm{i}}+\mathrm{P}_{\mathrm{j}}+\mathrm{E}_{\mathrm{ijk}},
$$

where $Y_{\mathrm{ijk}}$ is the dependent variable, $\mu=$ overall mean, $\mathrm{G}_{\mathrm{i}}=$ group effect ( $\mathrm{i}=1$ to 3$), \mathrm{P}_{\mathrm{j}}=$ experiment effect $(\mathrm{j}=1$ or 2$)$, and $\mathrm{E}_{\mathrm{ijk}}=$ random residual. The effect of parity was tested and was not significant for any variable that was tested and therefore excluded from the model. Mean separation was performed by using the PDIFF procedure with a Tukey adjustment in SAS (version 9.2).

The phenotypic Pearson correlations among all variables were analyzed by using PROC CORR in version 9.2 of SAS Institute (2002). Least squares means and adjusted standard errors of the mean are presented in the tables. Significance was considered as $P \leq 0.05$ and tendencies were reported for $0.05<P<0.10$.

\section{RESULTS}

\section{Correlations Analysis}

Figure 1 presents gross efficiencies as related to milk yield (A) and 4\% FCM yield (B). Gross efficiency increased with increasing milk $(\mathrm{r}=0.69 ; P<0.0001)$ and 
A

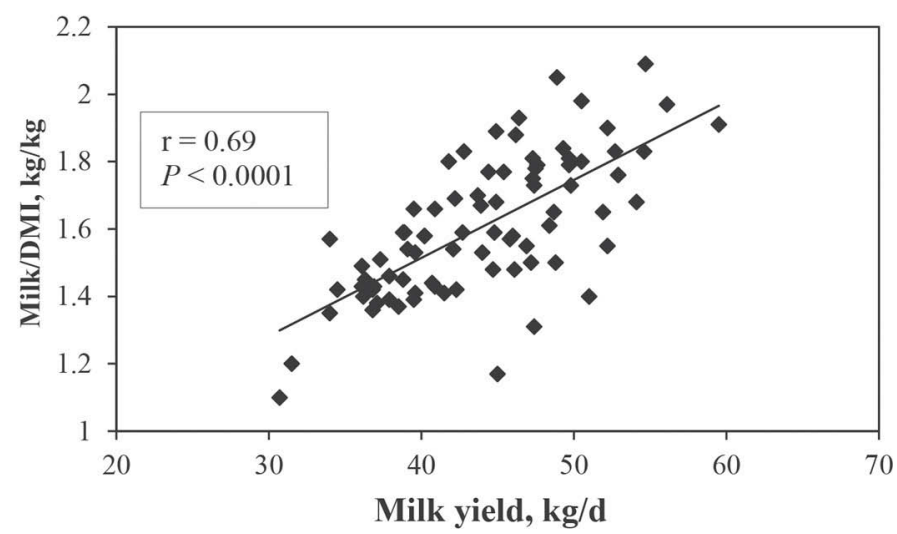

B

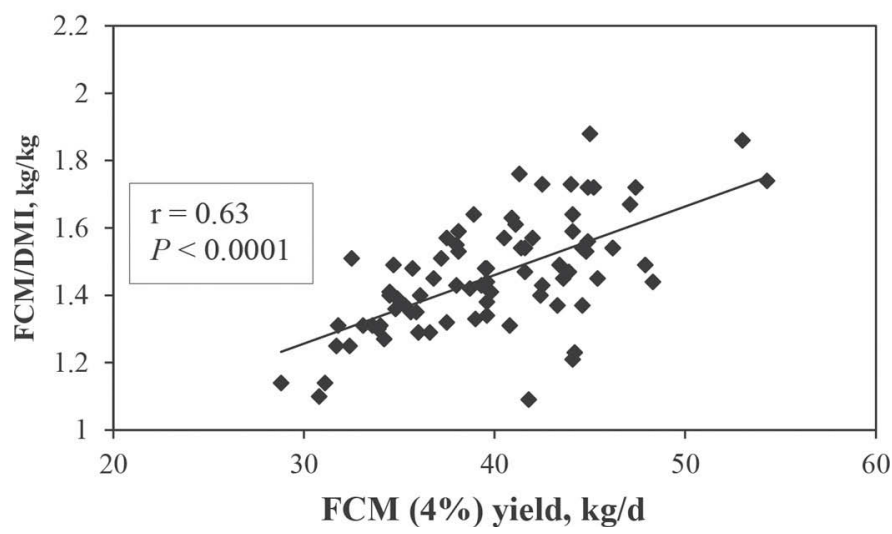

Figure 1. Gross production efficiency of milk (A) and $4 \%$ FCM (B) yields, as related to measured DMI of data collected from 82 midlactation dairy cows during 91 or $98 \mathrm{~d}$.

FCM $(\mathrm{r}=0.63 ; P<0.0001)$ yields. Conversely to their behavior with respect to yields, the behavior of gross efficiencies with respect to BW were negative (Figure 2 ). The production efficiencies of milk (panel $\mathrm{A} ; \mathrm{r}=$ $-0.61 ; P<0.0001$ ), FCM (panel $\mathrm{B} ; \mathrm{r}=-0.66 ; P<$ 0.0001 ), and ECM (panel $\mathrm{C} ; \mathrm{r}=-0.62 ; P<0.0001$ ) all decreased with increasing BW.

The marginal efficiencies of milk, FCM, and ECM production with respect to feed (DM) intake are presented in Figure 3. The marginal efficiencies decreased with increasing DMI: for milk (panel A; $\mathrm{r}=-0.45 ; P$ $<0.0001$ ), FCM (panel B; $\mathrm{r}=-0.50 ; P<0.0001$ ), and ECM (panel $\mathrm{C} ; \mathrm{r}=-0.50 ; P<0.0001$ ). The marginal efficiencies of production of milk and FCM decreased with increasing $\mathrm{NE}_{\mathrm{L}}$ intake (data not presented): for milk production $(\mathrm{r}=-0.45 ; P<0.0002)$ and FCM production $(\mathrm{r}=-0.48 ; P<0.0001)$. The marginal efficiency of ECM production decreased with increasing $\mathrm{NE}_{\mathrm{L}}$ intake $(\mathrm{r}=-0.45 ; P<0.0001 ;$ Figure 4$)$.

The difference between predicted and measured BW gain was also calculated and is presented in Figure
5 ; the difference increased with increasing DMI ( $\mathrm{r}=$ $-0.68 ; P<0.0001)$.

\section{Division into 3 Subgroups According to Measured DMI}

Cows were divided into 3 subgroups according to measured DMI, as described above; the average DMI in LDMI, MDMI and HDMI groups was 24.8, 27.1,
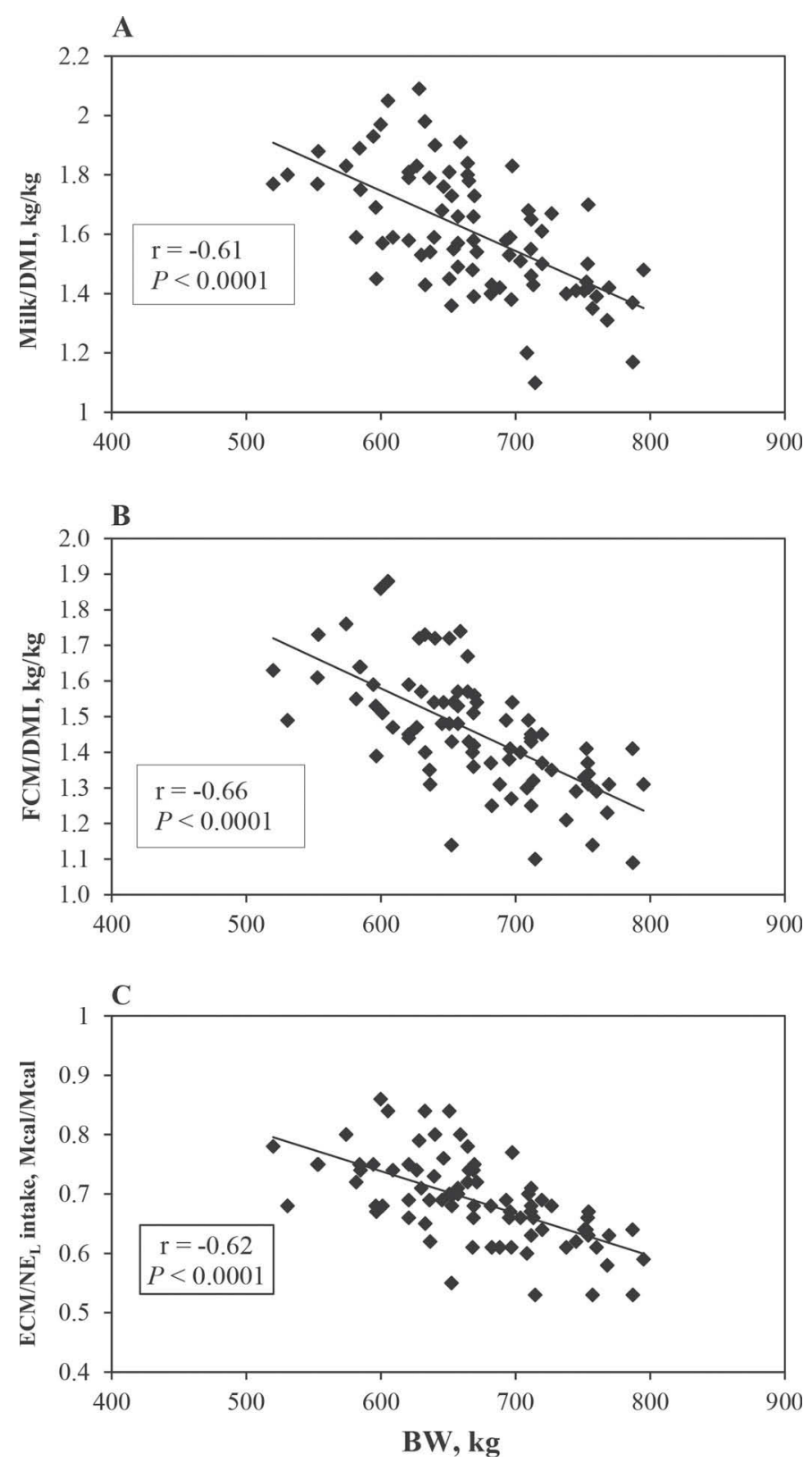

Figure 2. Gross production efficiencies of milk (A) and $4 \%$ FCM (B) yields, as related to BW, based on data collected from 82 midlactation dairy cows during 91 or $98 \mathrm{~d}$. Gross production efficiency of energy output in milk (ECM) from measured $\mathrm{NE}_{\mathrm{L}}$ consumed, as related to $\mathrm{BW}$, is presented in panel $\mathrm{C}$. 
and $30.8 \mathrm{~kg} / \mathrm{d}(\mathrm{SEM}=0.33)$, respectively (Table $2 ; P$ $<0.001$ ). The average milk yield was 11.3 and $12.3 \%$ greater in HDMI than in MDMI and LDMI, respectively (Table 2; $P<0.004$ ); similar results were observed for $4 \%$ FCM. The ECM yield was 12.0 and $11.1 \%$ higher in HDMI than in LDMI and MDMI, respectively (Table $2 ; P<0.018)$.

The average calculated energy balances were 1.38 , 2.28 , and $4.20 \mathrm{Mcal} / \mathrm{d}(\mathrm{SEM}=0.64)$ in LDMI, MDMI, and HDMI, respectively (Table $2 ; P<0.002$ ). The average $\mathrm{BW}$ was 41.1 and $78.2 \mathrm{~kg}$ higher in HDMI
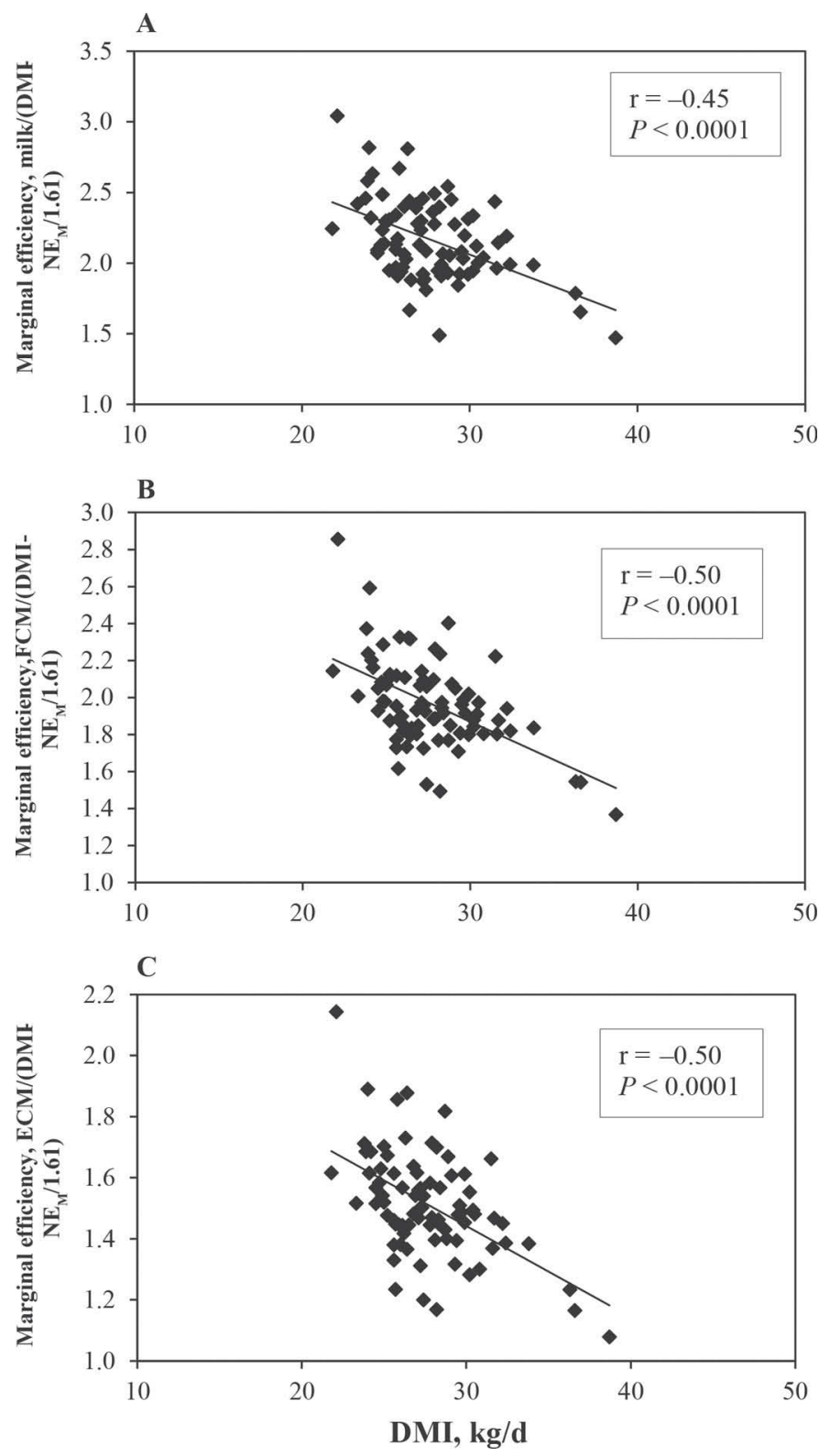

Figure 3. Marginal production efficiencies of yields of milk (A), $4 \%$ FCM (B), and energy output in milk (ECM; C), as related to measured DMI, based on data collected from 82 mid-lactation dairy cows during 91 or $98 \mathrm{~d}$.

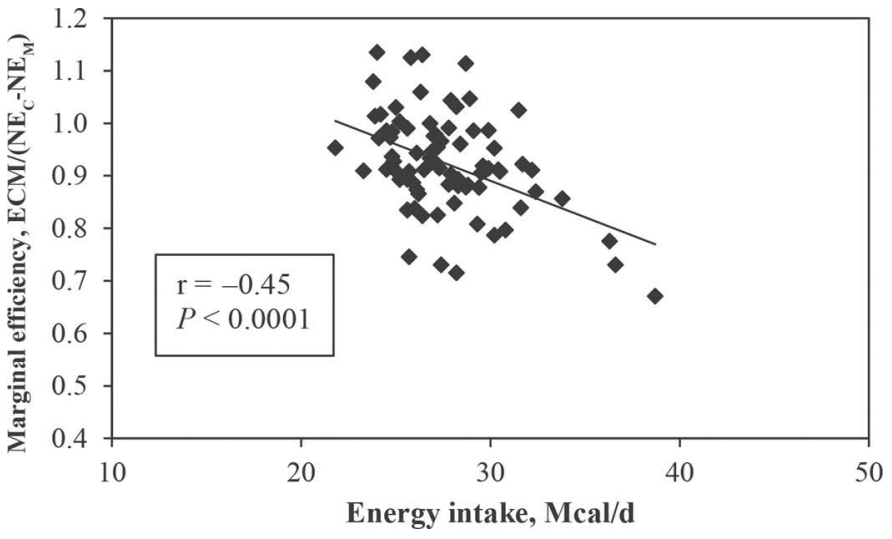

Figure 4. Marginal production efficiency of ECM, as related to measured $\mathrm{NE}_{\mathrm{L}}$ consumed, based on data collected from 82 mid-lactation dairy cows during 91 or $98 \mathrm{~d}$.

than in MDMI and LDMI, respectively (Table 2; $P<$ 0.014 ) and the energy required for maintenance was 10 and $5.2 \%$ higher in HDMI than in LDMI and MDMI, respectively (Table 2; $P<0.013$ ). The predicted BW gains for the whole study period were 22.9, 37.9, and $75.8 \mathrm{~kg}(\mathrm{SEM}=11.2)$ for the LDMI, MDMI, and HDMI groups, respectively (Table $2 ; P<0.001$ ). The difference between predicted and measured $\mathrm{BW}$ gain was negative in LDMI, and positive in both other groups; it was higher in HDMI than in either of the other groups (Table 2; $P<0.005$ ).

\section{Gross and Marginal Efficiency According to Subgroups}

Rate of conversion of DMI into milk or FCM tended to be higher in LDMI than in HDMI $(P<0.120$; Table $3)$. The conversion of consumed $\mathrm{NE}_{\mathrm{L}}$ to ECM did not differ between subgroups $(P<0.371)$.

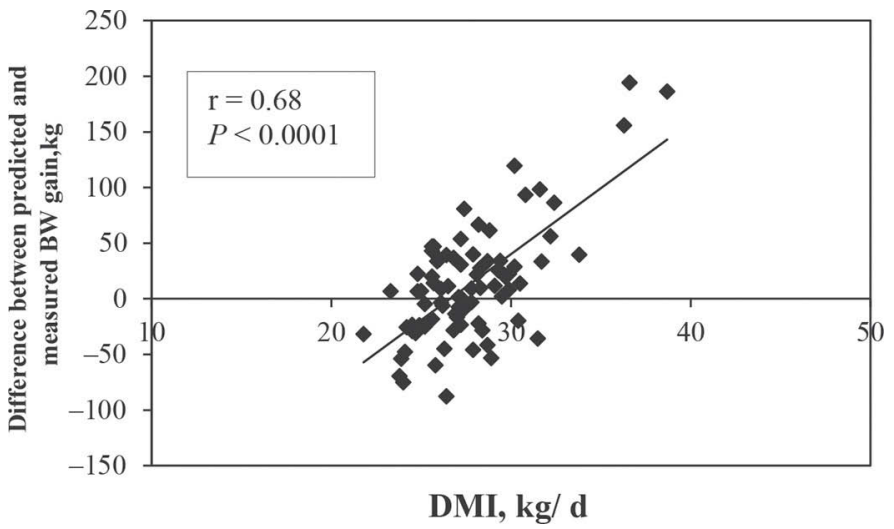

Figure 5. Differences between BW as predicted according to NRC (2001) model and measured BW gain, as related to DMI, based on data collected from 82 mid-lactation dairy cows during 91 or $98 \mathrm{~d}$. 
Table 2. Least squares means of feed intake, yields, energy balance, and measured and predicted BW of midlactation dairy cows grouped according to measured DMI

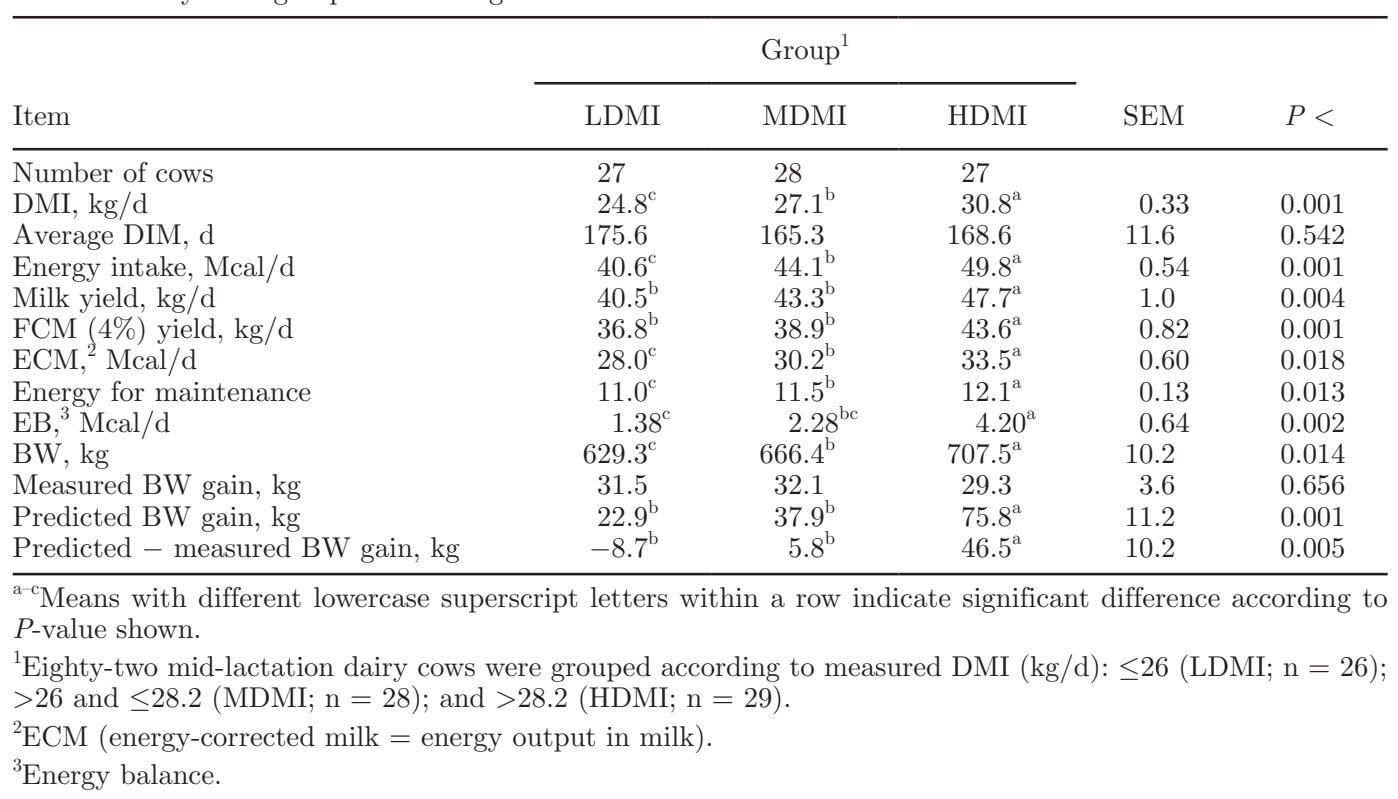

The marginal efficiency for milk yields from DMI was highest in LDMI (2.26), intermediate in MDMI (2.17), and lowest in HDMI (2.06; SEM $=0.05 ; P<0.005$; Table 4). Also, the marginal efficiency for FCM yields from DMI was higher in LDMI than in HDMI $(P<$ 0.003). The marginal efficiency for ECM from DMI was higher in LDMI (1.56) than in HDMI $(1.45 ; P<0.006)$.

The marginal efficiency for milk yields from consumed $\mathrm{NE}_{\mathrm{L}}$ was highest in LDMI (1.37), intermediate in MDMI (1.33), and lowest in HDMI (1.27; SEM = $0.03 ; P<0.018)$. The marginal efficiency for FCM yields from consumed $\mathrm{NE}_{\mathrm{L}}$ was higher in LDMI than in HDMI $(P<0.014)$, and that for ECM yield from consumed $\mathrm{NE}_{\mathrm{L}}$ was also higher in LDMI than in HDMI (Table 4; $P<0.028$ ).

The marginal efficiencies for ECM and BW gain (expressed as energy equivalent) from consumed $\mathrm{NE}_{\mathrm{L}}$ were found to be highest in LDMI (0.95), intermediate in MDMI (0.94), and lowest in HDMI $(0.91 ; P<0.030$; Table 4); those for ECM and BW gain (expressed as energy equivalent) from DMI were higher in the LDMI group than in the HDMI group (Table 4; $P<0.016$ ).

\section{DISCUSSION}

Gross and marginal production efficiencies of 82 midlactation high-yielding dairy cows were determined with respect to measured DMI. Gross production efficiency increased with increasing milk yield and, conversely, decreased with increasing BW. The marginal efficiencies for production variables diminished as DMI increased. In addition, the difference between predicted and measured BW gain increased with increasing feed intake.

\section{Intake, Yields, and Efficiency}

The gross efficiency of diets increased with increasing yields of milk, FCM, or ECM (Figure 1), and similar findings were obtained for marginal production effi-

Table 3. Least squares means of efficiency of conversion of DMI into milk and FCM (4\%) or of $\mathrm{NE}_{\mathrm{L}}$ consumed into energy output in milk (ECM)

\begin{tabular}{|c|c|c|c|c|c|}
\hline \multirow[b]{2}{*}{ Item } & \multicolumn{3}{|c|}{ Group $^{1}$} & \multirow[b]{2}{*}{ SEM } & \multirow[b]{2}{*}{$P<$} \\
\hline & LDMI & MDMI & HDMI & & \\
\hline Number of cows & 27 & 28 & 27 & & \\
\hline Milk to DMI, $\mathrm{kg} / \mathrm{kg}$ & 1.65 & 1.61 & 1.56 & 0.04 & 0.120 \\
\hline FCM to DMI, $\mathrm{kg} / \mathrm{kg}$ & 1.50 & 1.45 & 1.43 & 0.03 & 0.132 \\
\hline ECM to $\mathrm{NE}_{\mathrm{L}}$ consumed, Mcal/Mcal & 0.70 & 0.69 & 0.68 & 0.014 & 0.371 \\
\hline
\end{tabular}


Table 4. Least squares means of marginal efficiency of conversion of DMI into milk and of FCM (4\%) $\mathrm{NE}_{\mathrm{L}}$ consumed into energy output in milk (ECM)

\begin{tabular}{|c|c|c|c|c|c|}
\hline \multirow[b]{2}{*}{ Item } & \multicolumn{3}{|c|}{ Group $^{1}$} & \multirow[b]{2}{*}{ SEM } & \multirow[b]{2}{*}{$P<$} \\
\hline & LDMI & MDMI & HDMI & & \\
\hline Number of cows & 27 & 28 & 27 & & \\
\hline \multicolumn{6}{|l|}{ Marginal efficiency for DMI } \\
\hline Milk, $\mathrm{kg} / \mathrm{kg}$ & $2.26^{\mathrm{a}}$ & $2.17^{\mathrm{ab}}$ & $2.06^{\mathrm{c}}$ & 0.05 & 0.005 \\
\hline FCM $(4 \%), \mathrm{kg} / \mathrm{kg}$ & $2.05^{\mathrm{a}}$ & $1.95^{\mathrm{ab}}$ & $1.88^{\mathrm{b}}$ & 0.04 & 0.003 \\
\hline ECM, Mcal/kg & $1.56^{\mathrm{a}}$ & $1.51^{\mathrm{ab}}$ & $1.45^{\mathrm{b}}$ & 0.03 & 0.007 \\
\hline \multicolumn{6}{|c|}{ Marginal efficiency for $\mathrm{NE}_{\mathrm{L}}$ consumed } \\
\hline Milk, kg/Mcal & $1.37^{\mathrm{a}}$ & $1.33^{\mathrm{ab}}$ & $1.27^{\mathrm{c}}$ & 0.030 & 0.018 \\
\hline FCM $(4 \%), \mathrm{kg} /$ Mcal & $1.25^{\mathrm{a}}$ & $1.20^{\mathrm{ab}}$ & $1.16^{\mathrm{b}}$ & 0.024 & 0.014 \\
\hline ECM, Mcal/Mcal & $0.95^{\mathrm{a}}$ & $0.93^{\mathrm{ab}}$ & $0.89^{\mathrm{b}}$ & 0.018 & 0.028 \\
\hline \multicolumn{6}{|c|}{ Marginal efficiency for ECM + BW } \\
\hline From $\mathrm{NE}_{\mathrm{L}}$ consumed, $\mathrm{Mcal} / \mathrm{d}$ & $0.95^{\mathrm{a}}$ & $0.94^{\mathrm{ab}}$ & $0.91^{\mathrm{b}}$ & 0.015 & 0.030 \\
\hline From DMI, kg/d & $1.64^{\mathrm{a}}$ & $1.62^{\mathrm{ab}}$ & $1.61^{\mathrm{b}}$ & 0.0005 & 0.016 \\
\hline
\end{tabular}

ciency (data not shown). Similar results were reported by Britt et al. (2003), who examined the conversion efficiency of 34 herds at the herd level. Veerkamp (1998) reviewed several studies and found that genetic correlations between yield and intake ranged from 0.46 to 0.65 , which indicated a close association between feed intake and yield. In a study conducted in our laboratory (Honig et al., 2012), a management manipulation while the animals were subjected to heat stress increased DMI by $9.3 \%(2.1 \mathrm{~kg})$ and milk yields by $9.6 \%(3.5 \mathrm{~kg})$, which also demonstrated the close relationship between yield and intake. However, Rhoads et al. (2009) and Baumgard et al. (2011) demonstrated that reduced feed intake under heat stress accounted for approximately 35 to $50 \%$ of the milk yield decrease, a finding that cast doubt onto the close connection between intake and yield under stress conditions. Nevertheless, the discrepancy between studies might be explained as follows: under heat stress conditions, feed intake accounts for 35 to $50 \%$ of the milk yield decrease, but there is a close relationship between the increment in feed intake resulting from management manipulation and the increase in milk yield, as found in Honig et al. (2012).

Conversely, in the present study, marginal efficiencies decreased as intake increased (Figure 3); also, Table 4 shows that marginal efficiencies for all production parameters decreased as feed intake increased. The genetic selection that affects milk yields elicits several substantial changes in animal physiology to support lactation, and feed intake is one of the main variables affected by selection for high yields.

In Israel, genetic selection was never aimed to increase body size. Thus, although not supported by available data, it can be assumed that the digestive tract volume was not prominently enlarged; therefore, passage of digesta through the digestive tract would accelerate as intake increased (Vandehaar, 1998). Gabel et al. (2003) demonstrated that digestibility of diet components decreased as nutritional level increased; the rate of depression in digestibility was evaluated as $4.1 \%$ for each increase in nutritional level unit, which is very close to the $8 \%$ reduction in digestibility associated with changing from a $1 \times$ maintenance level to a $3 \times$ maintenance level reported in the United States NRC (2001).

The NRC (2001) states that diets with higher digestibility at maintenance exhibit greater digestibility depression when consumed above maintenance than those exhibiting low digestibility at maintenance. Also, the digestibility depression per increment of maintenance intake was usually greater as the proportion of concentrate in the diet increased (Wagner, 1965). The typical Israeli milking dairy cow ration comprises 65 to $67 \%$ concentrate and 33 to $35 \%$ forage, which ensures high digestibility if fed at maintenance level. Therefore, increased intake of the typical Israeli ration is expected to elicit a proportionately greater decrease in digestibility, which would affect marginal production efficiency. Bauman et al. (1985) concluded that there was little variability among cows in their ability to digest a given diet. This conclusion might be relevant for similar levels of intake, but not when feed intake levels differ. Additionally, increased milk production has led to increased gross feed efficiency, mainly through "dilution" of maintenance cost (Bauman et al., 1985). Therefore, increases in production level and, consequently, in feed intake will be less effective than expected in improving gross efficiency because the effect of "dilution" would be reduced. Thus, decreased marginal efficiency would 
be expected to be associated with increased intake in high-yielding dairy cows fed a high-concentrate diet such as the common Israeli milking-cow ration.

\section{BW and Efficiency}

In the present study, a negative phenotypic correlation ( -0.61 to -0.66 ; Figure 2$)$ between BW and gross production efficiency variables was found. In previous research, the correlation between intake and $\mathrm{BW}$ was not consistent and depended on the stage of lactation at which BW was measured, because of the confounding effects of body mobilization (Veerkamp, 1998). However, in the present study, the measurements of all cows were taken after the peak of lactation to avoid the confounding effect of body reserve use, and indeed, except for 2 animals, all cows gained BW during the experiments. This association between BW and efficiency can also be seen in Table 3, which shows that HDMI cows, which had the lowest efficiency, were about $11 \%$ heavier than those in either of the other groups. This negative phenotypic correlation between $\mathrm{BW}$ and efficiency traits, which also was reported by Vallimont et al. $(2010,2011)$, indicates that larger cows are less feed efficient than smaller ones. Hence, the adverse effect of body size and weight on efficiency traits should be taken into account in selection programs and indices.

Similarly to gross efficiency, marginal efficiencies of production variables decreased with increasing BW (r $=-0.58$ to -0.62$)$. Metabolic body size determines maintenance cost, and the fixed cost of maintenance has a negative effect on gross efficiency. Also, BW has a negative effect on marginal efficiency in high-yielding cows despite the relatively low proportion of total energy intake expended for maintenance in these cows, an average of $26 \pm 2 \%$ in the present study. Davey et al. (1983) concluded that the maintenance requirement was not influenced by genetic merit for milk yield. Indeed, we assume that the fixed cost for maintenance is similar between low- and high-yielding cows of similar BW. However, this assumption may not be accurate, because of the close correlation between yield and intake. High rates of feed intake might increase the maintenance energy cost, because of the higher rates of digestion, absorption, and metabolism necessitated by the larger amount of feed consumed by the highthan the low-yield cow. Furthermore, under heat stress, maintenance costs were estimated to be increased by as much as 25\% (NRC, 1989), and Fox and Tylutki (1998) suggested the increase may be greater than $30 \%$. Not all of these factors are always taken into account by nutritionists when formulating rations for high-yielding dairy cows.

\section{Intake, Marginal Efficiency, and Predicted BW Gain}

Except for 2 cows, all those in the present study increased BW by an average of $30.9 \pm 18 \mathrm{~kg}$. The predicted BW gain was based on the EB calculation, which takes into account the $\mathrm{NE}_{\mathrm{L}}$ derived from food. As seen in Figure 5, the difference between predicted and measured BW gain increased with increasing DMI. This means that in cows consuming large amounts of feed, the BW gain predicted by the NRC (2001) model is over-estimated. There are 3 possible reasons for this: (1) maintenance costs are higher in high- than in lowconsuming cows; (2) $\mathrm{NE}_{\mathrm{L}}$ derived from high intake of feed is lower than estimated, because of decreased marginal efficiency; and (3) energy required for BW gain in high-yield, high-consuming cows is higher than that estimated by the NRC (2001) model.

Furthermore, the NRC (2001) model assumes that $\mathrm{NE}_{\mathrm{L}}$ depression increases with increasing above-maintenance intake, which means that the marginal efficiency for energy intake would remain constant; conversely, that of DM would decrease because of decreasing $\mathrm{NE}_{\mathrm{L}}$ derived from food, so that the incremental NE intake would decrease with increasing energy intake. However, in the present study, marginal efficiency for ECM decreased with increasing energy intake, albeit to a lesser extent than with DM intake (Figure 4 and panel $\mathrm{C}$ in Figure 3, respectively). This meant that the estimated depression in energy density for feedstuffs, as estimated by the NRC (2001) model, was still low for cows that consume very large amounts of feed; under the NRC system, there is incomplete compensation for energy loss caused by decreased digestibility associated with increased intake. However, it might be that for a wider range of multiples of maintenance than was found in the present study (i.e., $3.9 \pm 0.3$ ), the NRC (2001) model would be more accurate.

From the present findings, which demonstrated reduced marginal efficiency in high-consuming cows, we can conclude that the energy derived from feed in such cows is overestimated. No new data are available on the maintenance cost and energy required for BW gain in high-yielding cows. However, we can assume that the large difference between predicted and measured BW gain in the present study could be attributed to all 3 aforementioned reasons.

\section{Production and Intake}

As in the present study, close correlation between yield and intake was reported elsewhere (Veerkamp, 1998). This close association between intake and yield raises the old (and substantial) question of what comes 
first: intake or production? In other words, is milk production driven by intake or vice versa? The NRC (2001) concluded that intake is driven by milk production, but this question has central consequences on future production efficiency. If high genetic merit for production triggers high intake, it means that mammary gland requirements, rather than those of the whole animal, drive intake. This also means that continuing selection for milk yields would trigger increasing intake and further decrease in marginal production efficiency. Because a cow eats amounts and not concentrations, it compensates for decreased marginal efficiency by increasing its intake. It should be noted that despite losses in digestive efficiency, increased DMI leads to increased supplies of digestible nutrients. Nutrient partitioning is a major component of productive efficiency (Bauman et al., 1985), and nutrients are preferentially directed for milk synthesis, as shown in the present study. If nutrients were not preferentially directed for milk synthesis, we would expect that with additional intake more resources would be directed toward BW gain, and the difference between predicted and measured BW would diminish; however, this was not the case in the HDMI group. The negative effects of the actual nutrient partitioning in the high-yielding cow is mainly on BW gain, even in mid-lactation cows, as was demonstrated in the present study. This pattern of partitioning affects fertility and well-being, as manifested in, for example, reduced BCS and longevity, and increased incidence of metabolic imbalance and other health conditions, including lameness, mastitis, and cystic ovaries (Oltenacu and Broom, 2010).

Alternatively, if intake drives production, wholeanimal requirements would be prioritized over mammary gland needs, and more energy resources would be directed toward BW gain. The ultimate question concerns whether successful selection programs have developed an excellent cow or an outstanding mammary gland - a gland that dictates animal demands and is first to take its "share" of nutrient resources, at the expense of other animal needs, such as BW gain, fertility, and health. The observed continuous decline in fertility performance with increasing milk yield might support the latter hypothesis.

Ongoing research is being conducted worldwide to improve the production efficiency of the individual cow by direct selection for increased feed efficiency, and efforts are being made to include this economically important trait in the selection index. The main limitation is the need for large numbers of individual DMI records that requires expensive and unavailable facilities. Alternatively, using conformation or other traits as predictors for DMI have been tested with varied results (Manzanilla-Pech et al., 2015). Also, several methods have been developed to evaluate the relative feed efficiency of the individual cow; for example, using residual feed intake (Asher at al., 2014). In general, all these methods are based on gross efficiency calculations and are aimed at improving selection capabilities, but not other biological factors that may influence production efficiency. However, the decreasing marginal production efficiency presented in the current study demonstrates that continuous selection for high milk production (which is still the main goal in the dairy industry) without nutritional and management adaptations may lead to a breaking point at which a decrease in gross efficiency will arise. This will occur primarily because of the reduced effect of "dilution," as discussed above. Furthermore, the findings of the present study lead to the conclusion that it would be more efficient to optimize rather than maximize DMI. This could be achieved by nutritional manipulations aimed at increasing diet digestibility or providing denser nutrients in a diet designed to provide all quantitative and qualitative nutritional requirements within lower intake.

\section{CONCLUSIONS}

The present study demonstrated decreased marginal production efficiency with increased feed intake. Because high-yielding cows consume large amounts of food, the energy, and probably other nutrients, derived from each food intake increment decreases and, in a response chain, the cow continually increases its intake. This means that the outstanding mammary gland that we have developed dictates the cow's nutritional requirements, and the main negative effects are on BW gain, health, and fertility. Because of the close association between yield and intake, the principle of diminishing marginal productivity may explain why increasing milk production - and, consequently, intake - is not always the best way to enhance profitability. Thus, to preserve high production efficiency in the future, more attention should be given to optimizing rather than maximizing feed intake.

\section{ACKNOWLEDGMENTS}

This research was financially supported by the Israeli Dairy Board (Yehud, Israel; grant number 362-035814). The authors thank the entire staff of the experimental dairy farm at the Volcani Center (Bet Dagan, Israel) for their assistance with animal care.

\section{REFERENCES}

Asher, A., A. Shabtay, A. Haim, Y. Aharoni, J. Mirom, G. Adin, A. Tamir, A. Arieli, U. Moallem, I. Halachmi, A. Orlov, and A. 
Brosh. 2014. Time required to determine performance variables and production efficiency of lactating dairy cows. J. Dairy Sci. 97:4340-4353.

Bauman, D. E., S. N. McCutcheon, W. D. Steinhour, P. J. Eppard, and S. J. Sechen. 1985. Sources of variation and prospects for improvement of productive efficiency in the dairy cow-A review. J. Anim. Sci. 60:583-592.

Baumgard, L. H., J. B. Wheelock, S. R. Sanders, C. E. Moore, H. B. Green, M. R. Waldron, and R. P. Rhoads. 2011. Postabsorptive carbohydrate adaptations to heat stress and monensin supplementation in lactating Holstein cows. J. Dairy Sci. 94:5620-5633.

Britt, J. S., R. C. Thomas, N. C. Speer, and M. B. Hall. 2003. Efficiency of converting nutrient dry matter to milk in Holstein herds. J. Dairy Sci. 86:3796-3801.

Capper, J. L., R. A. Cady, and D. E. Bauman. 2009. The environmental impact of dairy production: 1944 compared with 2007. J. Anim. Sci. 87:2160-2167.

Colucci, P. E., L. E. Chase, and P. J. Van Soest. 1982. Level of feed intake and diet digestibility in dairy cattle. J. Dairy Sci. 65:14451456.

Connor, E. E., J. L. Hutchison, K. M. Olson, and H. D. Norman. 2012. Triennial lactation symposium: Opportunities for improving milk production efficiency in dairy cattle. J. Anim. Sci. 90:1687-1694.

Davey, A. W. F., C. Grainger, D. D. S. Mackenzie, D. S. Flux, G. F. Wilson, I. M. Brookes, and C. W. Holmes. 1983. Nutritional and physiological studies of differences between Friesian cows of high or low genetic merit. Proc. N.Z. Soc. Anim. Prod. 43:67-70.

Fox, D. G., and T. P. Tylutki. 1998. Accounting for the effects of environment on the nutrient requirements of dairy cattle. J. Dairy Sci. 81:3085-3095.

Gabel, M., B. Pieper, K. Friedel, M. Radke, A. Hagemann, J. Voigt, and S. Kuhla. 2003. Influence of nutrition level on digestibility in high yielding cows and effects on energy evaluation systems. J. Dairy Sci. 86:3992-3998.

Honig, H., J. Miron, H. Lehrer, S. Jackoby, M. Zachut, A. Zinou, Y. Portnick, and U. Moallem. 2012. Performance and welfare of highyielding dairy cows subjected to 5 or 8 cooling sessions daily under hot and humid climate. J. Dairy Sci. 95:3736-3742. http://dx.doi. org $/ 10.3168 /$ jds.2011-5054

IDF. 2000. IDF Standard 141c:2000 (Determination of milk fat, protein and lactose content - Guidance on the operation of mid-infrared instruments. International Dairy Federation, Brussels, Belgium.).
Manzanilla-Pech, C. I. V., R. F. Veerkamp, R. J. Tempelman, M. L. van Pelt, K. A. Weigel, M. VandeHaar, T. J. Lawlor, D. M. Spurlock, L. E. Armentano, C. R. Staples, M. Hanigan, and Y. De Haas. 2016. Genetic parameters between feed-intake-related traits and conformation in 2 separate dairy populations - the Netherlands and United States. J. Dairy Sci. 99:443-457.

NRC. 1989. Nutrient Requirements of Dairy Cattle. 6th ed. Natl. Acad. Sci., Washington, DC.

NRC. 2001. Nutrient Requirements of Dairy Cattle. 7th ed. Natl. Acad. Sci., Washington, DC.

Oltenacu, P. A., and D. M. Broom. 2010. The impact of genetic selection for increased milk yield on the welfare of dairy cows. Anim. Welf. 19:39-49.

Reed, K. F., L. E. Moraes, D. P. Casper, and E. Kebreab. 2015. Predicting nitrogen excretion from cattle. J. Dairy Sci. 98:3025-3035.

Rhoads, M. L., R. P. Rhoads, M. J. VanBaale, R. J. Collier, S. R. Sanders, W. J. Weber, B. A. Crooker, and L. H. Baumgard. 2009. Effects of heat stress and plane of nutrition on lactating Holstein cows: I. Production, metabolism, and aspects of circulating somatotropin. J. Dairy Sci. 92:1986-1997.

SAS Institute. 2002. SAS User's Guide: Statistics. Version 9.2. SAS Institute Inc., Cary, NC.

Vallimont, J. E., C. D. Dechow, J. M. Daubert, M. W. Dekleva, J. W. Blum, C. M. Barlieb, W. Liu, G. A. Varga, A. J. Heinrichs, and C. R. Baumrucker. 2010. Genetic parameters of feed intake, production, body weight, body condition score, and selected type traits of Holstein cows in commercial tie-stall barns. J. Dairy Sci. 93:4892-4901.

Vallimont, J. E., C. D. Dechow, J. M. Daubert, M. W. Dekleva, J. W. Blum, C. M. Barlieb, W. Liu, G. A. Varga, A. J. Heinrichs, and C. R. Baumrucker. 2011. Short communication: Heritability of gross feed efficiency and associations with yield, intake, residual intake, body weight, and body condition score in 11 commercial Pennsylvania tie stalls. J. Dairy Sci. 94:2108-2113.

Vandehaar, M. J. 1998. Efficiency of nutrient use and relationship to profitability on dairy farms. J. Dairy Sci. $81: 272-282$.

Veerkamp, R. F. 1998. Selection for economic efficiency of dairy cattle using information on live weight and feed intake: A review. J. Dairy Sci. 81:1109-1119.

Wagner, D. G. 1965. Studies on the energy requirements of high producing dairy cows. PhD Thesis. Cornell Univ., Ithaca, NY. 